\title{
ADDITIONAL RADIOCARBON DATE FROM DANTE OUTWASH FAN, KING VALLEY, AND DATING OF THE LATE WISCONSIN GLACIAL MAXIMUM IN WESTERN TASMANIA
}

\author{
by Eric A. Colhoun and Sean J. Fitzsimons
}

(with one table and two text-figures)

Colhoun, E.A. \& Fitzsimons, S.J., 1996 (30:vi): Additional radiocarbon date from Dante outwash fan, King Valley, and dating of the late Wisconsin glacial maximum in western Tasmania. Pap. Proc. R. Soc. Tasm. 130(1): 81-84.

https://doi.org/10.26749/rstpp.130.1.81 ISSN 0070-4703. Department of Geography, University of Newcastle, Callaghan, NSW, Australia 2308 (EAC); and Department of Geography, University of Otago, PO Box 56, Dunedin, New Zealand (SJF).

A radiocarbon date of $19100 \pm 100$ yr BP (SUA 2856) closely dates the maximum extent of glacier ice at Lake Beatrice in the upper Dante Rivulet during the Late Wisconsin in western Tasmania. Study of the Dante Glacier outwash fan deposits shows that they overlie a palaeosol and an older outwash gravel formation, and are interstratified with fluvial silts containing transported organic detritus deposited by flooding of the King River. Examination of available radiocarbon dates obtained from the palaeosol and interstratified silts shows that the palaeosol, Dante outwash and fluvial silt sequence was formed during a relatively short period preceding and around the peak of the Late Wisconsin glacial stade (18-20 kyr BP). The data suggest that the Dante Glacier extended to its end moraine limits for only a short time. Key Words: glacier ice, outwash, palaeosol, Dante Formation, Tasmania.

\section{THE DANTE SECTION}

During the Late Wisconsin glacial stade $(<25$ and $>10 \mathrm{k} \mathrm{yr}$ BP) (locally the Late Margaret Glaciation), the West Coast Range of Tasmaniaacted as a snowfence east of which cirque and valley glaciers and a thin ice cap were developed on the Lake Dora plateau. The limits of these ice masses are defined by impressive end moraines at Lake Margaret in the southwest, by the Tyndall and Lake Rolleston moraines in the north, and by moraines adjacent to and south of Lake Beatrice in the upper part of the Dante Rivulet valley (Colhoun 1985, Kiernan 1980) (fig.1). Outside the Lake Beatrice moraines, a large outwash fan adjacent to Dante Rivulet extends to the western bank of the upper King Valley and, prior to the flooding of Lake Burbury, the outwash deposits were exposed in a section of c. $300 \mathrm{~m}$ length on the west bank, half a kilometre downstream of the confluence of the Dante Rivulet and King River, and at $230 \mathrm{~m}$ altitude (145'40'30"E and 42'3'30"S; Grid ref. 894451 on Franklin Sheet 8013 Series R661, 1:100 000 Topographic Survey, Australia). The section varies in height from c. $5-10 \mathrm{~m}$ as seen in figure 2, where the stratigraphic column described by Gibson et al. (1987) occurs $100 \mathrm{~m}$ south of that described in this paper. The section exposes the most important sequence of deposits found so far for dating the maximum Late Wisconsin ice extent in Tasmania.

The stratigraphic column described by Kiernan (1980) and Gibson et al. (1987) (fig.2) showed a lower ourwash gravel that was initially assigned to the Comstock Formation (Kiernan 1980, 1983), because of its stratigraphic position and geographic location, but which, because of the relative lack of weathering rinds on igneous rock clasts, was noted by Gibson et al. (1987) as possibly being younger. Further investigations by Fitzsimons et al. (1992) indicated that this lower outwash gravel was probably part of the Chamouni Formation formed by an ice advance that postdated the Comstock Formation of the Penultimate or Henty Glaciation and predated the Dante Formation of the Late Wisconsin Margaret Glaciation in the West Coast Range-King Valley region. The Chamouni ice advance is tentatively assigned to the Early Wisconsin cold stade (for definition of formations and glaciations (see Fitzsimons et al.1992: 9, Table 2).

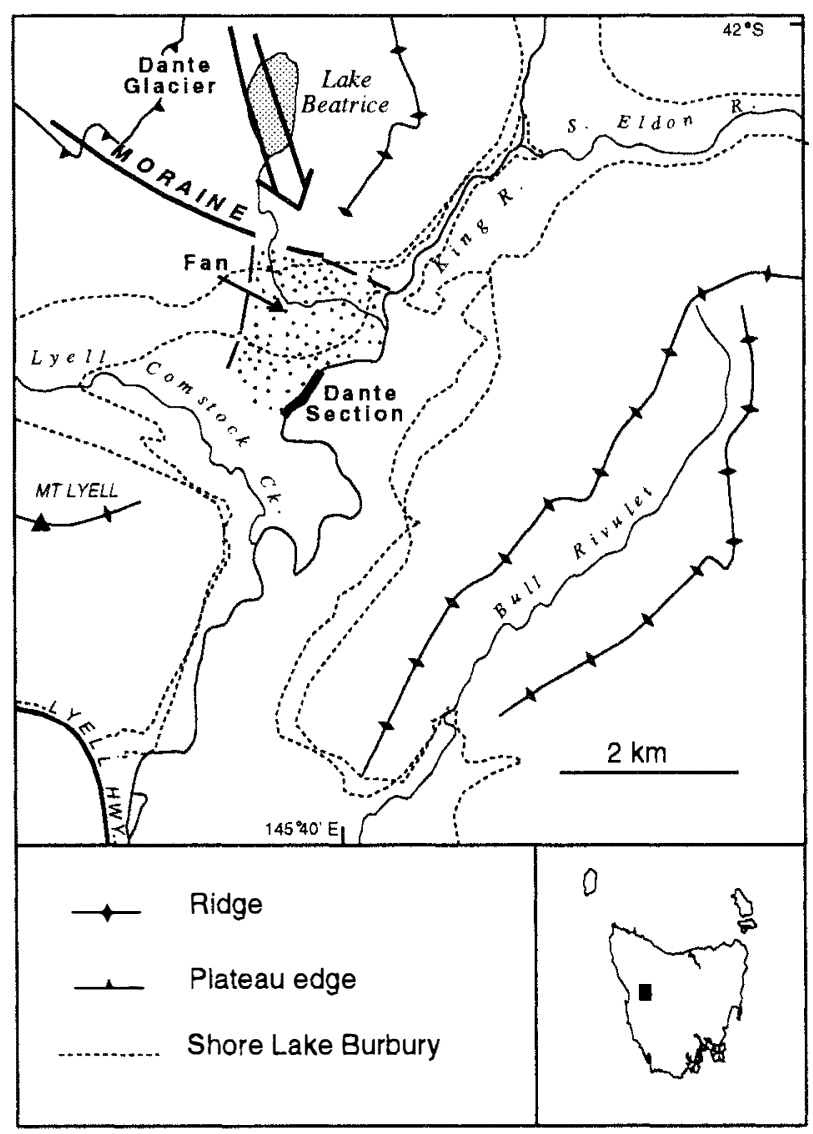

FIG. 1 - Location of the Dante Section in the upper King Valley, the Dante outwash fan and Lake Beatrice end moraines. 
The lower outwash is overlain by a thin horizon of organic silt with a distinct surface alpine-humus palaeosol including roots of plants and cushions of Donatia novaezelandiae in growth position. The large Donatia shown in Gibson et al. (1987, Plate 1) was buried in flowering condition by a thin bed of silt and fine sand that contained drifted wood fragments and was formed in an aquatic environment. The silt, palaeosol and overlying fluvial silt and fine sand were formed during the King Interval, the time succeeding the glaciation that formed the lower outwash and preceding the Dante ice advance that formed the upper outwash. The Dante Formation was shown to consist of a bed of fine sand and silt overlain by c. $3 \mathrm{~m}$ of outwash gravel.

\section{NEW DATA}

Re-examination of the deposits described by Gibson et al. (1987) and examination of the thickest sequence of deposits about $100 \mathrm{~m}$ upstream provide stratigraphic column 2 (fig.2) and allow further interpretation of the origin of some of the deposits. The observations confirm the stratigraphy and origin of the sediments in the lower part of the sequence as consisting of an outwash sand and gravel that is of post Comstock and pre-Dante age, that could relate to retreat of the Chamouni ice advance of Fitzsimons et al. (1992). The observations also indicate that the silt and fine sand beds beneach and above the palaeosol containing the Donatia are stratigraphically continuous throughour the section. The interpretation that the silt and fine sand bed overlying the palaeosol was deposited in an aquatic environment is confirmed. It is suggested that this bed and the silt bed underlying the palaeosol were deposited by overbank flooding of the King River, and that the wood and charcoal fragments were drifted into position from proximal sources upstream. The fine sand and silt bed shown in column 1 as proglacial is inorganic and finely laminated and does appear to be proglacial. It lenses out northward and does not extend to the site of column 2. The overlying Dante ourwash sequence commences at $1-1.05 \mathrm{~m}$ above the base of column 2 . The beds of outwash sand and gravel are interstratified with beds of silt and fine sand that are frequently organic, and are of fluviatile origin.

The interstratified sequence consists of 23 lithostratigraphic units with a total thickness of c. $8.3 \mathrm{~m}$. Thirteen of the units are shown in column 2, which had to be condensed, as some beds are too thin to be shown (particularly in the upper part). The column is capped by $0.7 \mathrm{~m}$ of Holocene peat. The lithostratigraphic units of Dante outwash consisted of bedded inorganic sands, small pebbles and medium to coarse gravels composed of local Owen

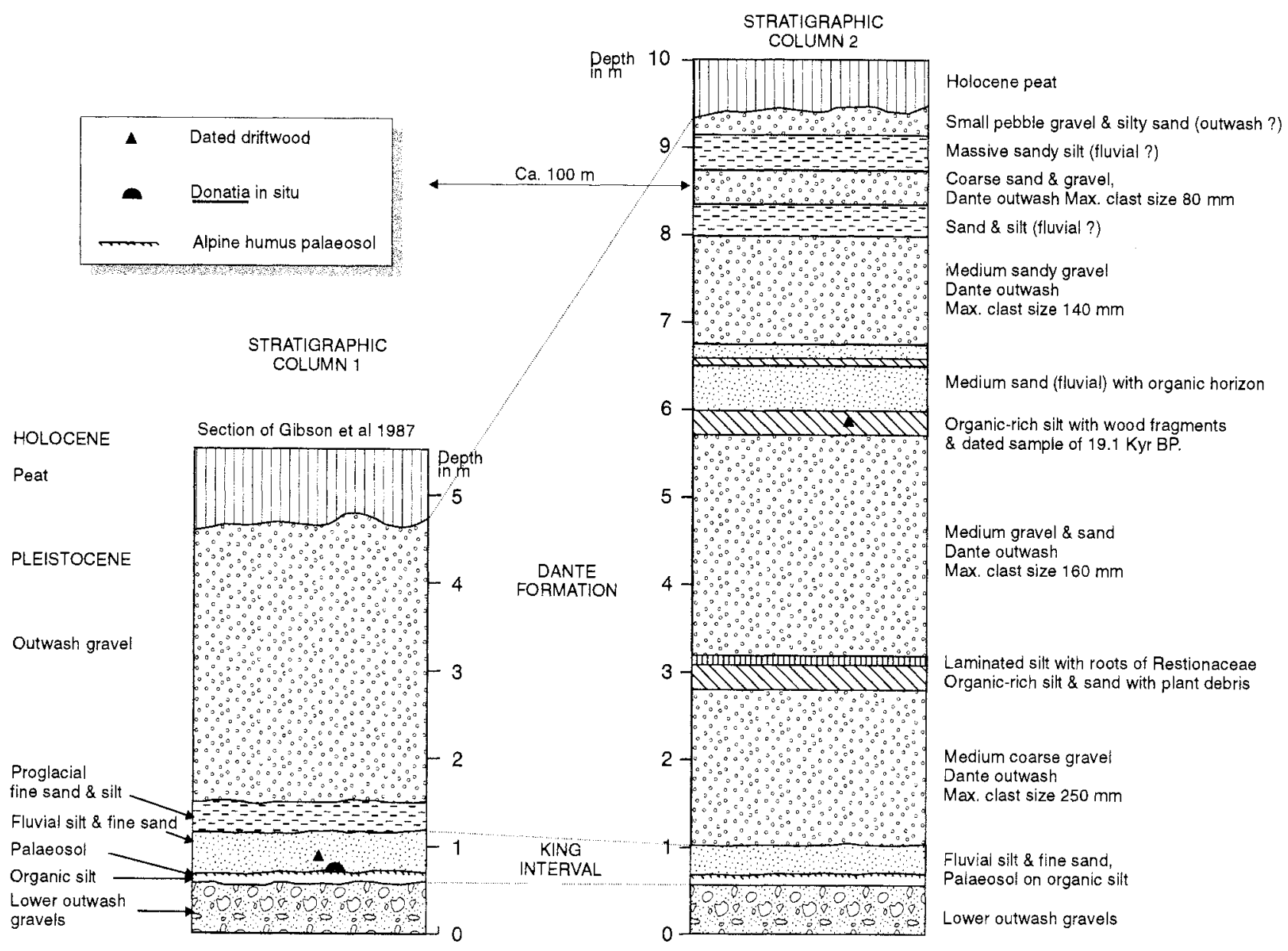

FIG. 2 - Stratigraphic columns showing the relationship of the outwash deposits of the Dante Formation to the alluvial deposits of the King River, the palacosol and lower outwash deposit (after Gibson et al. 1987, Colhoun \& Fitzsimons, this paper). 
Conglomerates and quartzite clasts derived from the conglomerate. In addirion, there are unweathered volcanic clasts derived from the Mt Read Volcanics, that crop out north and west of the site, and Jurassic dolerites transported from Mt Sedgwick $5 \mathrm{~km}$ to the northwest, or derived from older glacial deposits that contain abundant Jurassic dolerites from the Mt Eldon area in the upper King Valley. The interbedded units of organic silt and fine sand concaining finely divided charcoal fragments and drifted organic detritus contrast strongly with the inorganic outwash deposits. They are identical with overbank alluvial deposits rhat can be observed on the flood plains of western Tasmanian rivers and indicate deposition from repeated flooding of the upper King River catchment. Though interstratified with deposits of the Dante Formation they have a different origin and source.

Sedimentary evidence from the deposits in the Dante outwash fan allows some further interpretations of the extent and nature of the Dante ice advance and retreat. Firstly, the interstratified nature of the outwash and fluvial sediments shows that the site occurs in the distal part of the outwash fan and that the melrwater flows from the ice limit at the end moraines, south of Lake Beatrice, and overbank flooding, in the King Valley, were contemporary. The variation in thickness of columns 1 and 2 reflects the transverse convex surface of the outwash fan. The contrast between no interstratified alluvial silt and sand beds in the Dante Formation in column 1 and many in column 2 probably reflects the close proximity of a meander of rhe King River to column 2 during the period of accumulation of glacial outwash. In column 2 rhe maximum size of clast nored in the ourwash gravel units decreases upwards from $250 \mathrm{~mm}$ through $160 \mathrm{~mm}, 140 \mathrm{~mm}, 80 \mathrm{~mm}$ to $20-30$ $\mathrm{mm}$. This indicates a gradual loss in competence of the transporting agent and implies either retreat of ice from the end moraine during deposition of the fan or reduction in meltwater velocity. Either way the sedimeritary evidence indicates that the outwash fan was built after the ice had attained its maximum limit, south of Lake Beatrice, which is the maximum extent of ice of the West Coast glacial system.

\section{DATING AND SIGNIFICANCE OF THE DANTE SITE}

The Dance Site in the upper King Valley is the only site in Tasmania, or in Australia, having regard for the limited extent of glaciation in the Mt Kosciusko region, where the maximum extent of ice during the Late Wisconsin can be dated by virtue of the interstratification of the outwash sands and gravels with contemporaneous fluvial deposits. Elsewhere in Tasmania, radiocarbon dated sediments in cirque lakes occupied by ice or associated with moraines formed during the Late Wisconsin mainly postdate ice retreat. The oldest date of $17700 \pm 400$ yr BP (SUA 1359) occurs in the cirque basin of Ooze Lake, at $880 \mathrm{~m}$ altitude in southern Tasmania. The oldest date of $13400 \pm 600 \mathrm{yr}$ BP (SUA 2188) for northern Tasmania was obtained near the base of lake sediments inside an end moraine, at $575 \mathrm{~m}$ altitude at Dublin Bog in the Mersey Valley. In western Tasmania, the oldest dates that mark the commencement of post last glaciation organic sedimentation occur in a bog and lake that lie outside the Late Wisconsin ice limits. The dates are $13010 \pm 130 \mathrm{yr}$ BP (SUA 2723) at Governor Bog (180) $\mathrm{m}$ altitude) in the middle King Valley and $14200 \pm 230 \mathrm{yr}$ BP at Lake Selina ( $516 \mathrm{~m}$ altitude) in the West Coast Range (Macphail \& Colhoun 1985, Colhoun et al. 1991a, Colhoun et al. 1991b, Colhoun et al. 1996).

The dates obtained by Kiernan (1980) and Gibson et al. (1987) from the Dante Site closely predate the extension of ice to its maximum limit south of Lake Beatrice and the deposition of the Dante outwash fan but they do not date it (table 1)

Pollen and macroscopic plant evidence obtained by Gibson et al. (1987) from the alluvial silr underlying the palaeosol and $100 \mathrm{~m}$ downstream of column 1 showed that the environment was cold and comparable with the modern

TABLE 1

Radiocarbon dates from the Dante Site, western Tasmania

\begin{tabular}{lll}
\hline Lab. no. & Date 14C yr BP & \multicolumn{1}{c}{ Comment } \\
\hline SUA 2856 & $19100 \pm 100$ & $\begin{array}{l}\text { Wood fragment from alluvial silt c. } 5.8 \mathrm{~m} \\
\text { above base column } 2\end{array}$ \\
ANU 2533 & $18800 \pm 500$ & $\begin{array}{l}\text { Wood fragment from alluvial silt c. } 0.8 \mathrm{~m} \\
\text { above base column } 1\end{array}$ \\
SUA 2154 & $21180 \pm 370$ & $\begin{array}{l}\text { Donatia bolster c. } 0.75 \mathrm{~m} \text { above base } \\
\text { column } 1\end{array}$ \\
SUA 2155 & $20100 \pm 470$ & $\begin{array}{l}\text { Twigs in alluvial silt } 100 \mathrm{~m} \text { downstream of } \\
\text { column } 1 \text { and below palaeosol on which } \\
\text { Donatia grew }\end{array}$ \\
\hline
\end{tabular}


alpine zone prior to formation of the palaeosol and emplacement of the Dante outwash. Donatia bolsters are normally characteristic of the alpine zone above $1000 \mathrm{~m}$ and their presence supports the interpretation of cold alpine conditions for formation of the humic palaeosol. The dates of $20.1 \mathrm{kyr} \mathrm{BP}$ and $21.18 \mathrm{kyr} \mathrm{BP}$ are not significantly different at $2 \sigma$ (i.e. standard deviations). Thus, the palaeosol must have been formed rapidly after deposition of the silt.

The radiocarbon date on the small picce of driftwood from the fluvial silt $0.1 \mathrm{~m}$ above the palaeosol and $0.8 \mathrm{~m}$ above the base of column 1 dated by Kiernan (1980) to $18.8 \mathrm{kyr} \mathrm{BP}$ is not significantly different from the silt underlying the palaeosol but is significantly different from the age of the Donatia at $2 \sigma$, though the difference is small. Kiernan regarded this date of $18.8 \mathrm{kyr} \mathrm{BP}$ as dating the maximum ice advance but, as the fluvial silt underlies the proglacial fine sand and silt in column 1, it must slightly precede the maximum. The new date of $19.1 \mathrm{kyr}$ BP obtained on wood from fluvial silts interstratified within the main body of the Dante outwash gravels is not significantly different at $1 \sigma$ from the date obtained by Kiernan immediately below the outwash. The date confirms that the maximum ice advance of the West Coast glacial system to the moraines south of Lake Beatrice, during the Late Wisconsin cold stade, occurred at $19.1 \mathrm{kyr}$ BP. The nature of the interstratified sediments and the location of the new date above the middle of the outwash sequence suggests that the outwash fan was deposited rapidly and that the ice did not remain for a long time at the end moraines.

This $19100 \pm 100 \mathrm{yr}$ BP (SUA 2856) date for the maximum Late Wisconsin ice extent of the West Coast glacial system of Tasmania is closely comparable with dates obtained for the Late Wisconsin stade in western New Zealand and in Chile. In Westland, South Island, New Zealand the Late Wisconsin cold stade is represented by the Larrikins Formation which was deposited by an ice advance that commenced somewhat before $22.3 \mathrm{kyr}$ BP and culminated at c. $18 \mathrm{kyr} \mathrm{BP}$, or a little later (Suggate 1990). In Chile, the Late Wisconsin maximum ice advance constructed end moraines around the western ends of several of the southern Chilean lakes along the foot of the Andes. Radiocarbon dating of the moraine sequences, particularly at Lago Llanquihue, shows that Llanquihue II moraine was formed by ice that advanced after $30 \mathrm{kyr} \mathrm{BP}$ and reached its maximum position between 20-19 kyr BP (Porter 1981). The comparison indicates that the maximum extension of ice during the Late Wisconsin cold stade in the three glaciated Southern Hemisphere mid-latitudes regions was closely equivalent and occurred between 20 and $18 \mathrm{kyr} \mathrm{BP}$.

\section{ACKNOWLEDGEMENT}

The authors thank Kevin Kiernan for comments on the manuscript. This is Contribution No. 9 of the Geomorphology and Quaternary Science Research Unit of the Department of Geography, University of Newcastle, NSW, Australia.

\section{REFERENCES}

Colhoun, E.A., 1985. Glaciations of rhe West Coast Range, Tasmania, Quat. Res. 24: 39-59.

Colhoun, E.A., Pola, J.S. \& Barton, C.E., 1996. Late Pleistocene Vegetation and Climate History of Lake Selina, Western Tasmania. Quat. Internat. (in press).

Colmoun, E.A., van de Geer, G. \& Hannan, D., 1991a. Late Glacial and Holocene Vegetation History at Dublin Bog, North-Central Tasmania. Aust. Geogr.Stud. 29 (2): 337 354.

Colhoun, E.A., van de Geer, G. \& Fitzsimons, S.J., 1991b. Late Glacial and Holocene vegetation history at Governor Bog, King Valley, western Tasmania, Australia. J. Quat. Sci. 6(1): 55-66.

Fitzsimons, S.J., Colmoun, E.A., van de Geer, G. \& Pollington, M., 1992. The Quaternary Geology and Glaciation of the King Valley. Bull. Geol. Surv. Tasm. 69: 57 pp.

Gibson, N., Kiernan, K.W. \& Macphail, M.K., 1987. A fossil bolster plant from the King River, Tasmania. Pap. Proc. R. Soc. Tasm. 121:35-42.

Kiernan, K.W., 1980. Pleistocene glaciation of the central West Coast Range, Tasmania. Unpubl. BA Hons thesis, Dep. Geogr., Univ. Tasm.

KIERNAN, K.W., 1983. Weathering evidence for an additional glacial stage in Tasmania. Aust. Geogr. Stud. 21: 197_ 220.

MaCphaIl, M.K. \& Colhoun, E.A., 1985. Late Last Glacial Vegetation, Climates and Fire Activity in Southwest Tasmania. Search $16(1-2)$ : 43-45.

PORTER, S.C., 1981. Pleistocene glaciation in the Southern Lake District of Chile. Quat. Res. 16: 263-292.

Suggate, R.P., 1990. Late Pliocene and Quaternary Glaciations of New Zealand. Quat. Sci. Rev. 9 (2/3): 175-198.

(accepted 14 May 1996) 